IRA-International Journal of Management \& Social Sciences

ISSN 2455-2267; Vol.05, Issue 03 (2016)

Pg. no. 436-442

Institute of Research Advances

http://research-advances.org/index.php/RAJMSS

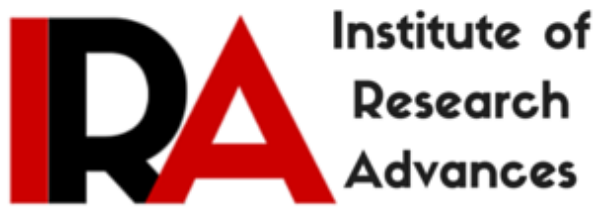

\title{
Impact of Corporate Social Responsibility on the Firm's Performance and Development in Context of Indian Companies
}

\author{
${ }^{1}$ Vikrant Vikram Singh \\ Assistant Professor, Amity Business School, \\ Amity University Madhya Pradesh, India. \\ ${ }^{2}$ Dr. Manoj Pandey \\ HOD, Amity Business School, \\ Amity University Madhya Pradesh, India. \\ ${ }^{3}$ Prof. (Dr.) Anil Vashisht \\ Director, Amity Business School, \\ Amity University Madhya Pradesh, India.
}

Type of Review: Peer Reviewed.

DOI: http://dx.doi.org/10.21013/jmss.v5.n3.p6

\section{How to cite this paper:}

Singh, V., Pandey, M., \& Vashisht, A. (2016). Impact of Corporate Social Responsibility on the Firm's Performance and Development in Context of Indian Companies. IRA-International Journal of Management \& Social Sciences (ISSN 24552267), 5(3), 436-442. doi:http://dx.doi.org/10.21013/jmss.v5.n3.p6

(C) Institute of Research Advances

\section{(cc) $\mathrm{BY}-\mathrm{NO}$}

This work is licensed under a Creative Commons Attribution-Non Commercial 4.0 International License subject to proper citation to the publication source of the work.

Disclaimer: The scholarly papers as reviewed and published by the Institute of Research Advances (IRA) are the views and opinions of their respective authors and are not the views or opinions of the IRA. The IRA disclaims of any harm or loss caused due to the published content to any party. 


\begin{abstract}
The study looks at the Corporate Social Responsibility (CSR) techniques and exercises of firms as revealed in yearly reports and investigates its linkages to bookkeeping and market execution of firms. The study looks at the yearly reports of a specimen of 30 firms (out of 50) fitting in with the benchmark list of the National Stock Exchange of India and tracks these reports for proofs of CSR exercises over a five year period from 2010 to 2015. The study utilizes substance investigation to study CSR revelation and characterizes and rates these exercises utilizing things from a set up scale took after by development of class shrewd CSR records. The relationship of these files with firm execution is investigated through a pooled relapse model in the wake of provisioning for control variables and slack impacts. The study finds that CSR reporting may not be having any critical effect on bookkeeping and market execution of the firm in the fleeting yet environment situated CSR exposure may be adversely identified with the business sector execution of the firm. The concentrate additionally finds that organizations concentrate intensely on representative and client arranged CSR and the methods of CSR ventures are more contributory as opposed to participative in nature.
\end{abstract}

Keywords: Corporate Social Responsibility; Firm Performance; Accountability; Sustainability; Reporting

\title{
Introduction
}

CSR has been drilled by organizations in the created world bigly. The majority of the substantial private colleges in the United States (US) were setup as a piece of CSR exercises attempted by expansive corporates. A considerable measure of multinational organizations contributes towards the advancement of social orders in which they work. A most eminent sample is Shell, an Anglo-Dutch multinational oil and gas organization, which backings the neighborhood groups in Nigeria. In India, huge scale generous exercises were embraced post-autonomy, which prompted the setting up of the absolute most prestigious organizations of expert instruction. Organizations likewise contributed by making gifts to nonadministrative associations (NGOs) and their own particular trusts, which were deductible under Section $80 \mathrm{G}$ of the Income Tax (IT) Act. Then again, the gifts were not straightforward and needed responsibility. The aggregate of CSR can be resolved from the three words this expression contains: corporate, social and responsibility. CSR covers the relationship between enterprises or other substantial associations and the social orders with which they interface. CSR likewise incorporates the obligations that are characteristic on both sides of these connections. CSR characterizes society in its broadest sense, and on numerous levels, to incorporate all partners and constituent gatherings that keep up a progressing enthusiasm for the association's operations. CSR is for the most part comprehended to be the way an organization adjusts the practical, ecological and social parts of its operations, tending to the desires of its partners.

The relations between CSR and FP are for the most part uncertain, yet positive relations between the two have been accounted for in the majority of the studies proposing an instrumental introduction of CSR activities. It recommends the arrangement of social objective with the business objective where CSR is considered as a vital instrument to advance the monetary target of the firm. Administrators predict huge quality increments in firm execution because of fortified partner relations. Administration scholars contend that by enhancing CSR towards partners, firm execution is enlarged. 


\section{Literature Review}

FEI YU (2011) tested for abnormal stock market returns from membership in the National Environmental Performance Track (NEPT) program. His analysis proved that there is strong evidence that acceptance of a facility to the NEPT adds significantly to the market capitalization of the accepted firms. Corporate social responsibility can be financially rewarding for firms and voluntary programs of the EPA can be an effective complement to performance-based regulatory instruments.

Çtefan Claudiu Câescu, et al. (2011) suggested that corporate management includes in its whole methodology a series of specific instruments that are subject to strategic management. They are the result of the evolution of the concept of management and have as central element the strategy considered rightly as an essential tool of modern management. At higher organizational level the corporate strategies adopted are specific to the business portfolio, competitive advantage strategies, business development strategies, brand strategies and corporate social responsibility strategies.

Coral Ingley, et al. (2011) examined the stakeholder representation and results of a recent survey conducted among a large sample of New Zealand directors are presented. The findings suggest that these traditionally oriented boards are increasingly inwardly focused and are without an agenda for building and managing shareholder and stakeholder relations. Accordingly they suggested that these traditionally oriented boards are increasingly inwardly focused and are without an agenda for building and managing shareholder and stakeholder relations. Accordingly, such boards are unlikely to regard stakeholder engagement as a serious strategic issue and are thus also likely to miss significant opportunities in the changed business environment to benefit from stakeholder support.

Christian Homburg, et al. (2010) Relying on instrumental stakeholder theory, these researchers develop and empirically test a framework of the influence of a supplier's CSR engagement on organizational customer outcomes. They came to know that from an examination of 200 cross-industry suppliercustomer dyads reveal positive effects of two facets of a supplier's CSR efforts on customer loyalty through distinct mechanisms. Business practice GSR fosters customers' trust, whereas philanthropic CSR strengthens customer-company identification. In their study they distinguish a supplier's actual GSR engagement and customers' perception of these GSR activities. In addition, they considered central contingency factors reflecting uncertainty and dependence in business-to-business relationships that determine the effectiveness of GSR.

Paul C. Godfrey (2007) studied the current state of the art across a number of academic disciplines, from accounting to management to theology. In a world that is increasingly global and pluralistic, progress in our understanding of CSR must include theorizing around the micro-level processes practicing managers engage in when allocating resources toward social initiatives, as well as refined measurement of the outcomes of those initiatives on stakeholder and shareholder interests. They posed five questions that scholars from each of these disciplines should address as the CSR field moves forward. We hope our questions provoke deeper thinking and greater rigor and attention to detail in this important area of business research.

Ruth V. Aguilera, et al. (2007) provided a multilevel theoretical model to understand why business organizations are increasingly engaging in corporate social responsibility (CSR) initiatives and thereby exhibiting the potential to exert positive social change. In their study they integrated theories of organizational justice, corporate governance, and varieties of capitalism to argue that organizations are pressured to engage in CSR by many different actors, each driven by instrumental, relational, and moral motives. Finally they concluded their study by highlighting empirical questions for future research and discussing some managerial implications. 


\section{Research Methodology}

Different studies have embraced principally three various types of ways to deal with concentrating on CSR by firms - unmistakable, instrumentalist and standardizing. Distinct exploration concentrates more on what firms do, regulating examination bases its presumptions that organizations have moral duty towards CSR and the instrumental methodology accept that tending to partner hobbies are fixed to monetary returns. This study accept the enlightening and instrumental methodology of firms towards CSR and hopes to connection social and monetary execution of firm

The objective of the research is to assess the implications of firms' CSR strategies on accounting and market returns of the firm. Specifically, the following aspects of CSR were studied.

The yearly reports were broke down utilizing substance examination as this is a built up system in social and natural reporting (Abbott and Monsen, 1979). We arranged sentences from the yearly reports alluding to different CSR exercises attempted by the firm. It is trusted that sentences give complete, significant and solid information for further investigation (Milne and Adler, 1999).

For the purpose of the present study, we have focussed only on external and societal stakeholders. Thus we have used a subset of items developed by Turker which relate to the principle 4 to 8 as suggested by the Ministry of Corporate Affairs, Government of India. Principles 1,2,3 and 9 relate more to the internal working and governance of the firm and may be driven more by a profit motive than principles 4 to 8 . Thus the compiled CSR activity information was classified across various following categories using items from the scale developed by Turker which also conform to the classification provided by Wheeler and Sillanpaa. These items were further rated on a 7 point likert type scale. Independent rating for 15 companies selected from the 30 companies was carried out and the inter-rater reliability kappa of individual items was 0.772 with $\mathrm{p}<0.001$, which may be considered to be acceptable.

Also, our study of CSR activities of 30 firms revealed that firms focus on one or more of the following 8 areas - 1) Environment 2) Local Community Development 3) Global Issues 4) Education and Health initiatives 5) Philanthropy 6) Civic Issues 7) Employee Oriented and 8) Customer Orientated. Thus the areas where the firms were focussing their CSR activities were ranked from 1 to 8 . However our analysis of annual reports over 5 years (2010-2015) suggests that data around CSR especially spends are very scarce and only public sector companies indicate CSR spends in their annual reports. Thus after ranking CSR activities of firms, we analysed how firms spend on CSR which were again classified into 5 categories - 1) Cash 2) In kind 3) Volunteers 4) Loans and 5) Others. We recorded from our collected information, which of the channels have firms used and maintained a Yes/No classification against each of the above.

Table: Results of Regression Analysis of CSR Indexes on Accounting Returns (ROA)

\begin{tabular}{|l|l|l|l|l|}
\hline Model & Variables & $\begin{array}{l}\text { Standardized } \\
\text { Coefficients }\end{array}$ & $\mathbf{t}$ & Sig. \\
\hline $\mathbf{1}$ & PAT & 0.316 & 2.837 & 0.005 \\
\hline & Net Sales & -0.057 & -0.579 & 0.564 \\
\hline & Ownership & 0.354 & 3.426 & 0.001 \\
\hline $\mathbf{1 A}$ & PAT & 0.191 & 1.579 & 0.011 \\
\hline & Net Sales & -0.019 & -0.192 & 0.848 \\
\hline & Ownership & 0.345 & 3.359 & 0.001 \\
\hline & Stakeholder & 0.071 & 0.559 & 0.577 \\
\hline & Human Rights & 0.173 & 1.501 & 0.136 \\
\hline
\end{tabular}




\begin{tabular}{|l|l|l|l|l|}
\hline & Environment & 0.024 & 0.201 & 0.841 \\
\hline & Policy Advocacy & -0.225 & -2.301 & 0.023 \\
\hline & Inclusive Growth & -0.044 & -0.333 & 0.702 \\
\hline & PAT & 0.295 & 2.651 & 0.009 \\
\hline & Net Sales & -0.025 & -0.252 & 0.802 \\
\hline & Ownership & 0.28 & 2.663 & 0.009 \\
\hline & Stakeholder & 0.078 & 0.622 & 0.535 \\
\hline & Human Rights & 0.176 & 2.217 & 0.028 \\
\hline & Environment & 0.02 & 0.16 & 0.873 \\
\hline & Policy Advocacy & -0252 & -2.558 & 0.012 \\
\hline & Inclusive Growth & -0.139 & -1.176 & 0.242 \\
\hline & Cash & 0.119 & 1.326 & 0.188 \\
\hline & In kind & 0.146 & 1.522 & 0.131 \\
\hline & Volunteers & 0.175 & 1.857 & 0.066 \\
\hline & Loans & -0.162 & -1.681 & 0.096 \\
\hline
\end{tabular}

Table: Results of Regression Analysis of CSR Indexes on Market Returns (PE Ratio)

\begin{tabular}{|l|l|l|l|l|}
\hline Model & Variables & $\begin{array}{l}\text { Standardized } \\
\text { Coefficients }\end{array}$ & $\mathbf{t}$ & Sig \\
\hline $\mathbf{2}$ & PAT & 0.049 & 0.446 & 0.657 \\
\hline & Net Sales & 0.076 & -0.711 & 0.442 \\
\hline & Ownership & 0.355 & 3.48 & 0.001 \\
\hline 2A & PAT & 0.139 & 1.333 & 0.185 \\
\hline & Net Sales & -0.154 & -1.647 & 0.102 \\
\hline & Ownership & 0.34 & 3.555 & 0.001 \\
\hline & Stakeholder & -0.003 & -0.024. & 0.981 \\
\hline & Human Rights & -0.223 & -2.142 & 0.034 \\
\hline & Environment & -0.385 & -3.535 & 0.001 \\
\hline & Policy Advocacy & 0.196 & 2.146 & 0.034 \\
\hline & Inclusive Growth & 0.223 & 2.085 & 0.039 \\
\hline 2B & PAT & 0.123 & 1.179 & 0.241 \\
\hline & Net Sales & -0.165 & -1.777 & 0.078 \\
\hline & Ownership & 0.378 & 3.842 & 0 \\
\hline & Stakeholder & -0.024 & -0.207 & 0.837 \\
\hline & Human Rights & -0.211 & -1.813 & 0.073 \\
\hline & Environment & -381 & -3.319 & 0.001 \\
\hline & Policy Advocacy & 0.19 & 2.054 & 0.042 \\
\hline & Inclusive growth & 0.26 & 2.346 & 0.021 \\
\hline & Cash & -0.03 & -0.359 & 0.72 \\
\hline & In kind & 0.098 & 1.085 & 0.28 \\
\hline & Volunteers & -0.151 & -1.712 & 0.09 \\
\hline & Loans & 0.099 & 1.101 & 0273 \\
\hline
\end{tabular}


We utilized substance investigation systems utilized by other comparative studies. A coder with expert level degree was prepared in the different parts of CSR reporting by organizations. At the introductory stage the coder did not know the whole approach to be trailed by was told to gather and code different data identified with CSR unveiled by the organizations.

Table: Summary of CSR content of annual reports

\begin{tabular}{|c|c|c|c|c|c|c|c|c|c|}
\hline & 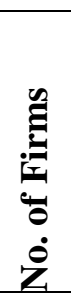 & 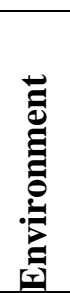 & 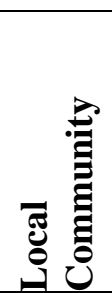 & $\begin{array}{l}\frac{n}{E} \\
\frac{0}{0} \\
\frac{\sigma}{0} \\
\frac{0}{0}\end{array}$ & 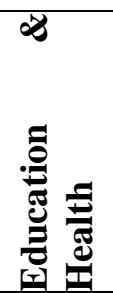 & & 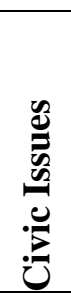 & 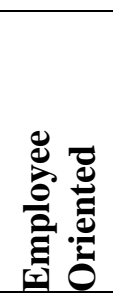 & 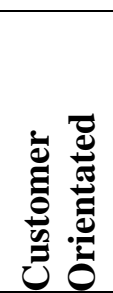 \\
\hline Automobiles & 3 & 6.7 & 4.0 & 7.0 & 3.7 & 7.0 & 6.7 & 8.0 & 8.0 \\
\hline Banking \& Finance & 6 & 7.0 & 4.3 & 7.7 & 3.3 & 6.0 & 6.7 & 7.5 & 8.0 \\
\hline Cement & 2 & 4.5 & 4.5 & 5.5 & 6.0 & 7.5 & 6.0 & 8.0 & 8.0 \\
\hline $\begin{array}{ll}\text { Construction } & \& \\
\text { Engineering } & \end{array}$ & 5 & 5.8 & 3.6 & 7.4 & 3.4 & 7.0 & 6.0 & 7.8 & 8.0 \\
\hline FMCG & 2 & 5.0 & 6.0 & 6.5 & 6.0 & 8.0 & 7.5 & 7.0 & 7.5 \\
\hline Information Technology & 2 & 6.0 & 5.0 & 6.0 & 4.0 & 7.5 & 7.5 & 6.0 & 7.0 \\
\hline Metals & 1 & 6.0 & 1.0 & 8.0 & 2.0 & 7.0 & 2.0 & 8.0 & 8.0 \\
\hline Oil \& Gas & 4 & 4.5 & 3.3 & 7.0 & 2.8 & 7.3 & 7.0 & 6.8 & 8.0 \\
\hline Pharmaceuticals & 1 & 8.0 & 6.0 & 5.0 & 3.0 & 8.0 & 6.0 & 8.0 & 8.0 \\
\hline Power & 2 & 7.5 & 3.0 & 8.0 & 2.5 & 5.0 & 3.5 & 7.5 & 8.0 \\
\hline Telecommunications & 2 & 5.0 & 4.5 & 5.5 & 4.0 & 5.0 & 6.5 & 6.5 & 7.0 \\
\hline & & 6.0 & 4.1 & 6.7 & 3.7 & 6.8 & 5.9 & 7.4 & 7.8 \\
\hline
\end{tabular}

\section{Conclusion}

The study offers various outcomes of enthusiasm on how CSR reporting is connected with monetary execution of the firm. To start with, from the relationship examination we find that CSR action reporting is not essentially associated with measures of bookkeeping returns like the ROA. Comparative discoveries remain constant for measures of business sector returns like the normal PE proportion, the main special case being that natural CSR exercises are contrarily connected. Comparable discoveries rise up out of the consequences of our relapse investigation. One of the conceivable elucidations could be that interest in CSR exercises by firms has a long haul return skyline and therefore is not reflected in returns in a tears time as all the money related variables in the model were slacked by a year just consequent to the CSR action being accounted for. Additionally, if there should be an occurrence of PE proportion, CSR exercises went for enhancing the regular habitat may be adversely seen as ecological quality can be considered as an open decent with no eliteness being workable for the firm just. Along these lines rehearsing supervisors ought to keep the long haul nature of CSR in their arranging skylines and speedy comes back from CSR exercises may not be conceivable in a yearly arranging skyline. Second, firms perhaps to their greatest advantage concentrate on worker and client situated CSR. However firms need to grow their CSR exercises to different territories of concern moreover. At long last, most firms show that 
they course their CSR spends through particular speculations money or kind however it was impractical for us to gather real CSR spend by firms. Notwithstanding these organizations need to investigate other conceivable streets for keep up these exercises like empowering volunteering by workers, giving advance plans and other conceivable ones which may be more participative as opposed to contributory in nature.

\section{References}

1. Yu,F.(2012)," Participation of firms in voluntary environmental protection programs: an analysis of corporate social responsibility and capital market performance", Contemporary Economic Policy(2012),30(1),13-28.

2. Santos, Nicholas J.C. and Laczniak, Gene R. (2012) "Marketing to the Base of the Pyramid: A Corporate Responsibility Approach with Case Inspired Strategies," Business and Politics: Vol.14: Iss. 1, Article 4.

3. Aseem Prakash and Jennifer J. Griffin(2012)," Corporate responsibility, multinational corporations, and nation states: An introduction", Business and Politics 2012; 14(3): 1-10.

4. Denise Baden(2014)," Look on the Bright Side: A Comparison of Positive and Negative Role Models in Business Ethics Education", Academy of Management Learning \& Education, 2014, Vol. 13, No. 2, 154-170.

5. Godgrey, Paul C. and Hatch, Nile W.(2007)," Researching Corporate Social Responsibility: An Agenda for the 21st Century", Journal of Business Ethics (2007) 70:87-98.

6. Simon Knox, Stan Maklan and Paul French(2005)," Corporate Social Responsibility: Exploring Stakeholder Relationships and Programme Reporting across Leading FTSE Companies", Journal of Business Ethics (2005) 61: 7-28.

7. Aguilera, Ruth V., Rupp, Deborah E.,Williams, Cynthia A. and Ganapathi,J.(2007)," Putting the S back in corporate social responsibility: a multilevel theory of social change in organizations", Academy of Management Review, 2007, Vol. 32, No. 3, 836-863.

8. Companies Bill 2012 as passed by Lok Sabha. (2012, December 27). Retrieved from http://www.mca.gov.in: http://www.mca.gov.in/Ministry_hn/pdf/The_Companies_Bill_2012.pdf .

9. Abbott, W. F., \& Monsen, R. J. (1979). On the Measurement of Corporate Social Responsibility: Self Reported Disclosures as a Method of Measuring Corporate Social Involvement. Academy of Management Journal, 510-15.

10. Alexander, G. J., \& Rogene, A. B. (1978). Corporate Social Responsibility and Stock Market Performance. Academy of Management Journal, 479-486.

11. Berman, S. L., Wicks, A. C., Kotha, S., \& Jones, T. M. (1999). Does stakeholder orientation matter? The relationship between stakeholder management models and firm financial performance. Academy of Management Journal, 42(5), 488-506. 